\title{
Time use by family caregivers of elderly with dementia: an integrative review
}

\author{
Uso do tempo por cuidadores familiares de idosos com demência: revisão integrativa \\ Uso del tiempo por cuidadores familiares de ancianos con demencia: revisión integrativa
}

Elcyana Bezerra Carvalho', Anita Liberalesso Neri'

'Universidade Estadual de Campinas. Campinas, São Paulo, Brazil.

How to cite this article:

Carvalho EB, Neri AL. Time use by family caregivers of elderly with dementia: an integrative review. Rev Bras Enferm [Internet]. 2018;71(suppl 2):893-904. [Thematic Issue: Health of the Elderly] DOI: http://dx.doi.org/10.1590/0034-7167-2017-0268

Submission: 05-10-2017 Approval: 10-16-2017

\begin{abstract}
Objective: To describe the development of measures used between 1993 and 2016 to evaluate time use by family caregivers of elderly with dementia and to find out the patterns of time use identified in the literature. Method: An integrative review of articles was performed, indexed by the following terms: time use management, family caregiver and elderly. Results: A total of 17 articles were found, of which seven were methodological. Among these seven articles, five were psychometric. The most frequently used measures were self-reporting (matrices, questionnaires and inventories), validated through objective measures of occurrence and duration. Longitudinal, prospective, clinical and correlational studies showed that care time covaries with the receptors' dependence and that the caregivers' subjective well-being is more affected by the time restriction to free choice activities than the burden resulting from obligatory activities. Final considerations: Valid self-reporting measures are widely used nowadays and they are considered to be effective to assess the objective and subjective costs of health care for dementia. Descriptors: Time; Dependence; Routine Activities; Long-lasting Care; Alzheimer's Disease.
\end{abstract}

\section{RESUMO}

Objetivo: Descrever a evolução das medidas utilizadas para a avaliação do uso do tempo por cuidadores familiares de idosos com demências, entre 1993 e 2016, e conhecer os padrões de uso do tempo identificados por essa literatura. Método: Revisão integrativa de artigos indexados pelos termos time use measurement, family caregiver e elderly. Resultados: Dezessete artigos, dentre os quais sete metodológicos. Dentre estes, cinco eram psicométricos. As medidas mais usadas foram de autorrelato (matrizes, questionários e inventários), validadas por medidas objetivas de ocorrência e duração. Estudos longitudinais, prospectivos, clínicos e correlacionais mostram que o tempo de cuidado covaria com a dependência do receptor e que o bemestar subjetivo do cuidador é mais afetado pela restrição do tempo para atividades de livre escolha do que pela sobrecarga decorrente das obrigatórias. Considerações finais: Medidas válidas de autorrelato são hoje amplamente usadas, consideradas como eficazes para avaliar custos objetivos e subjetivos do cuidado nas demências.

Descritores: Tempo; Dependência; Atividades Cotidianas; Assistência de Longa Duração; Doença de Alzheimer.

\section{RESUMEN}

Objetivo: Describir la evolución de las medidas utilizadas para la evaluación del uso del tiempo por cuidadores familiares de ancianos con demencias entre 1993 y 2016 y conocer los patrones de uso del tiempo identificados por esa literatura. Método: revisión integrativa de artículos indexados por los siguientes términos: time use measurement, family caregiver y elderly. Resultados: 17 artículos, entre los cuales siete metodológicos; de entre ellos, cinco eran psicométricos. Las medidas más usadas fueron de autoinforme (matrices, cuestionarios e inventarios), validadas por medidas objetivas de ocurrencia y duración. Los estudios longitudinales, prospectivos, clínicos y correlacionales muestran covarianza entre el tiempo de cuidado y la dependencia del receptor. Además, el bienestar subjetivo del cuidador es más afectado por la restricción del tiempo para actividades de libre elección que por la sobrecarga derivada de las actividades obligatorias. Consideraciones finales: Las 
medidas válidas de autoinforme son hoy ampliamente usadas y consideradas como eficaces para evaluar costos objetivos y subjetivos del cuidado en las demencias.

Descriptores: Tiempo; Dependencia; Actividades Cotidianas; Asistencia de Larga Duración; Enfermedad de Alzheimer.

\section{CORRESPONDING AUTHOR Elcyana Bezerra Carvalho E-mail: elcyana.b@gmail.com}

\section{INTRODUCTION}

The first study on time use by the elderly was performed by Beyer and Woods (1963) $)^{(1)}$, based on the time budget methodology, meaning "daily estimates of time spent on activities". It consists in the minute-by-minute reconstruction of the sequence and context of activities performed on the previous day, enabling the assessment of the type, frequency and duration of such activities. The data are recorded on a "time vs. activity" matrix including a period of observation of 24 hours, divided into 96 intervals of 15 minutes, supported by a procedure known as "Yesterday Interview".

The second study on time use by the elderly was performed by Havighurst, Neugarten and Tobin $(1969)^{(2)}$, supported by the Activity Theory and the concept of successful aging, which predominated at that time. It dealt with the adjustment of teachers and workers who retired from heavy industry in six European countries.

In the 1960s and 1970s, research on time use was dominated by the Economy, Psychology and Sociology of Organizations. It focused on the temporal organizations of work and leisure activities, paid an unpaid work, time dedicated for the regeneration and patterns of activities of adults and elderly in

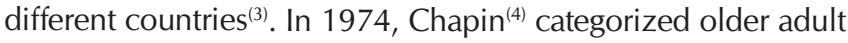
activities into two groups: obligatory and discretionary ones. The first ones leave little choice as they are associated with survival, while the other ones are more dependent on personal choices and connected to the fulfillment of the needs for affection, knowledge and pleasure. In Chapin's categorization, obligatory activities and work overlap, just as discretionary activities and pleasure overlap. This categorization was widely adopted in subsequent studies, despite the limitations inherent to the fact that elements of choice and obligation are not necessarily excluding, as they are not always clearly identifiable. This is because they are not equally distributed in different contexts and because they are influenced by social roles, especially gender roles. Lawton (1978)(5) discussed leisure activities among elderly, which were overvalued at that time, including them in the referral list of obligatory and discretionary activities. According to the author, elderly choices of leisure activities are controlled by the social values acquired during youth, current biological and social competences, changes to personal needs due to aging and facilitating or hindering effects of the external environment. This point of view guided the subsequent study on activities with institutionalized vulnerable elderly and it is considered to be valid until now.

Moss and Lawton (1982)(6) ${ }^{(6)}$ pere pioneers in the investigation of patterns of time use as indicators of life style, health and cognitive competence of elderly. In this study, the estimates of daily time spent on activities were collected through an interview about the previous day administered to 535 elderly individuals divided into four groups. The first one was formed by independent elderly recruited in the community; the second one by tenants living in public nursing homes; the third one by elderly who received intensive home care; and the fourth one by elderly whose names were included in a waiting list for admission to long-stay institutions. Following the trend established by previous studies on time use, activities were categorized into obligatory (personal care, shopping, home care, cooking, helping others and social participation) or discretionary (social interaction in and out of the family, religious activities, reading, watching $\mathrm{TV}$, listening to the radio, leisure, relaxation and rest).

Independent elderly individuals were found to spend more hours on obligatory activities performed indoors than on discretionary activities, although the higher the level of functional independence, the more hours are dedicated to activities performed individually and outdoors. Elderly individuals who were less independent spent more time resting and relaxing. Cognitive competence influenced the use of media, living alone, spending less time resting and more time with one's family. These data were also found in subsequent studies, as those led by Margret Baltes et al. ${ }^{(7-9)}$ and Pruchno and Rose et al. $(2002)^{(10)}$. Together with the studies conducted by Lawton et al., they are very popular in this area, thanks to the use of records of obligatory and discretionary activities, in intervals counted in minutes, including the entire waking time of elderly individuals. Other ways to assess time use by elderly derived from this method.

A new and important piece of evidence was described in another study. Lawton, Moss and Fulcomer (1986-1987)(11) observed that elderly individuals spent most of their waking time performing more appreciated discretionary activities, rather than their favorite obligatory activities. The more time these individuals spent interacting with friends and family, reading, watching TV, having fun with leisure activities indoors, or staying outdoors around the house, the more pleasure derived from such activities. These data led researchers to conclude that time use and the estimates of time use by the elderly are influenced by affective variables.

In 1993, Moss, Lawton, Kleber and Duhamel(12) published the results of the first known study on time use by family caregivers, based on the "Yesterday Interview"(1). They focused on daily records of time spent on obligatory and discretionary activities, before and after the institutionalization of elderly individuals. By showing that institutionalization leads to an increase in the number of hours dedicated to care, authors advanced towards understanding the burden of care for elderly with high physical and cognitive dependence, a theme that had already caught the attention of researchers dedicated to work associated with family caregivers' stress. The great contribution of this study was the system of categorization of activities of 
caregivers that would guide subsequent research: support for the elderly (instrumental, personal care, feeding, medical care, transport and contact with social agencies); obligatory activities (personal care, feeding, helping others, companionship, cooking, housekeeping, paid work and traveling); discretionary activities (interacting with one's family, interacting with friends, religion, watching $\mathrm{TV}$, listening to the radio, reading, leisure, rest and relaxation); social context (alone; with an older adult; with others, at home; with friends, with paid help and with others); and environmental context (at the caregiver's home, at the older adult's home and out of home).

In Brazil, the interest in the study of time use by the elderly is recent. As it occurred in other countries, the initial focus on this question was socio-demographic in nature. It translated into the inclusion of items about this theme in the Pesquisa Nacional por Amostras de Domicílio (PNAD - National Household Sample Survey) since 1996, although it did not aim to perform large population surveys about the physical, emotional and financial costs of elderly care. Years later, time use was the theme of studies performed with non-probabilistic restricted samples of active older Brazilian adults living in the community. The results of Doimo, Derntl and Lago (2008) ${ }^{(13)}$ Santos, Cartaxo, Silva, Moura and Freitas (2013) ${ }^{(14)}$; Emmel, Paganelli and Valio (2015) ${ }^{(15)}$ and Nunes and Emmel (2015) (16) were similar to those found in other countries. However, data from Brazilian studies on time use by family caregivers are not available.

Brazilian research on time use by informal caregivers of the elderly is at a level similar to the one that characterized its study nearly 30 years ago in countries which, at that time, were experiencing the final stages of aging of their respective populations. Nowadays, Brazil is experiencing population changes that are similar to those which have already occurred in such countries. Currently, there is an increase in the demand for caregivers of the elderly, while the availability of family caregivers decreases. This is a phenomenon of great impact on social protection and health systems, family and elderly individuals ${ }^{(17)}$.

Literature reviews are useful instruments when aiming to gather and summarize evidence about multiple studies on a certain theme that have been published, considering the fact that such data help one to make decisions about new research questions and methods to be adopted to answer them. Additionally, data obtained through literature reviews can be useful for the design of applied research and interventions. This relevance lies in the clarification of not only theoretical questions (How does a phenomenon occur? What defines it? What factors are they associated with?), but also methodological (How can certain information be obtained in a valid and reliable way?) and technological questions (How can a problem or complaint affecting certain individuals be resolved?).

In light of the review and literature previously described, the present study aimed to identify the main theoretical and methodological developments in research on time use by family caregivers of elderly with dementia, throughout the 25 years that followed Lawton's pioneering initiative to create valid measures for this phenomenon; as well as to find out what was revealed by these measures in terms of time management in support activities and in concurrent activities of a personal or social, obligatory or discretionary nature, performed by these individuals.

\section{OBJECTIVE}

The present study aimed to describe the development of measures used to assess time use by family caregivers of elderly with dementia, according to data shown in the literature between 1993, the year of the first publication on this theme, and 2016; as well as to identify the patterns of time use by caregivers found in the literature.

\section{METHOD}

An integrative literature review is a method that summarizes the studies available on a certain theme and guides practice, founded on scientific knowledge. This review considered the six stages of the process of development of an integrative review: 1) preparation of the guiding question, 2) search or sampling of the literature, 3) data collection, 4) critical analysis of the studies included, 5) discussion of results, and 6) presentation of the integrative review ${ }^{(18)}$. An integrative review on time use by family caregivers of elderly with dementia was performed, based on research data from articles published in international periodicals, between 1993 and 2016.

The databases consulted were as follows: Medical Literature Analysis and Retrieval System Online (MEDLINE/ PubMed), Biblioteca Virtual em Saúde sobre Literatura Latino-Americana e do Caribe em Ciências da Saúde and Scientific Electronic Library Online (BVS/LILACS and SciELo). Combinations of the following descriptors were used: time, time use, measurement, family caregiver, informal caregiver, elderly, older people and dementia. Searches were performed between April and June 2016 and updated on March $9^{\text {th }} 2017$, based on the same descriptors.

The eligibility criteria were as follows: research articles on time use by family caregivers of elderly with dementia, published in journals indexed in international database systems, in either English, Portuguese or Spanish, and fully available for reading. The inclusion criteria were as follows: review articles, theoretical articles, studies whose sample included formal caregivers exclusively, and studies with elderly receiving care who had other health conditions, not dementia. Comparative studies including family caregivers and formal caregivers were accepted. Articles indexed in more than one database or those that appeared among the list of articles indexed through two or more combinations of descriptors were considered only once.

Studies were selected through a consultation of databases performed by two authors, who alternated independent and joint article search and assessment techniques that met the inclusion criteria, firstly based on the analysis of titles and abstracts. The articles selected were fully read, aiming to be categorized into one of the three research groups defined for the review (time use patterns, time use measures, and 
relationships between objective time use measures and the subjective well-being of caregivers). A summary was made for each study, including the following information: authorship, year of publication, country, objective(s), methodology (participants, design, time use measure and other aspects of interest, and procedure) and results of interest.

\section{RESULTS}

The searches performed in the MEDLINE/PubMed revealed 29 articles that met the inclusion criteria. Among these, seven appeared two or more times, resulting in 12 exclusions. Figure 1 shows the details of the results found for each combination of terms used in the present study. The same combinations were used in searches in the BVS/LILACS/SciELo databases, although these did not lead to articles that were different from those already found.

A total of three articles were published in 1990; six between 2000 and 2008; and eight between 2010 and 2016. There are nine whose main authors are from the United States, one of which also included authors from 22 countries/members of the World Health Organization (WHO). Additionally, there was one that included researchers from Canada and European countries. Finally, Germany, Holland, Australia, Sweden, France, England and Singapore completed the list of nationalities leading articles reviewed in the present study. Chart 1 shows data on the articles included in this integrative literature review.

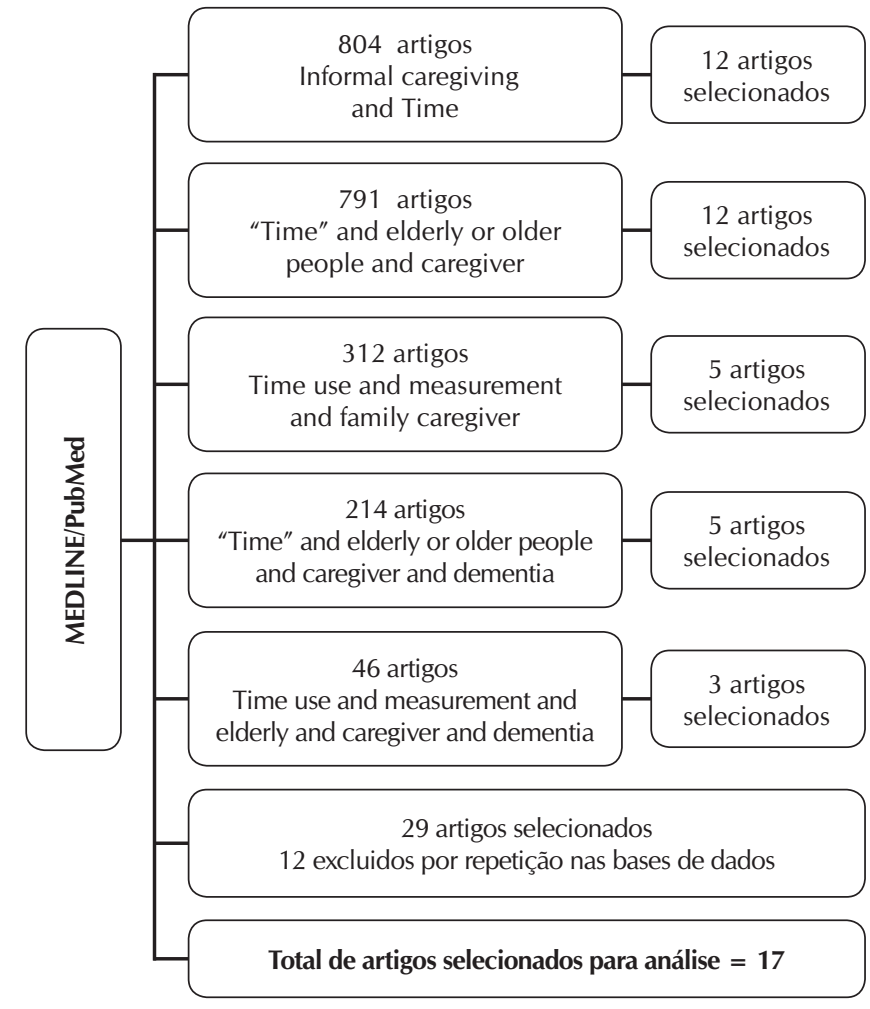

Figure 1 - Flow of selection of articles on time use by family caregivers of elderly with dementia, published between 1993 and 2016, Campinas, São Paulo, Brazil

Chart 1 - Studies on time use by family caregivers of elderly with dementia, indexed in international databases, published in English, Portuguese and Spanish, between 1993 and 2016, Campinas, São Paulo, Brazil

\begin{tabular}{|c|c|c|c|}
\hline $\begin{array}{l}\text { Authors, year } \\
\text { and country }\end{array}$ & Objective(s) & Design, participants, variables and measures & Results of interest \\
\hline $\begin{array}{l}\text { Moss MS, } \\
\text { Lawton MP, } \\
\text { Kleban MH, } \\
\text { Duhamel L, } \\
\text { 1993. USA }{ }^{(12)}\end{array}$ & $\begin{array}{l}\text { To describe the } \\
\text { estimates of "care } \\
\text { activities x time" } \\
\text { in daily records of } \\
\text { family caregivers, } \\
\text { before and after the } \\
\text { institutionalization } \\
\text { of elderly } \\
\text { individuals. }\end{array}$ & $\begin{array}{l}\text { In this study, } 165 \text { caregivers, included in } \\
\text { the waiting lists of geriatric clinics and state } \\
\text { geriatric clinic assessment programs, were } \\
\text { submitted to baseline (Time 1) and follow-up } \\
\text { measures, five months later (Time 2), when } 77 \\
\text { elderly individuals had been institutionalized. } \\
\text { "Yesterday Interview" and "time x activity } \\
\text { matrix" were used to collect estimates of time } \\
\text { spent on care activities (time budgets) during } \\
\text { each of the } 96 \text { periods of } 15 \text { minutes in which } \\
\text { one day of waking time was divided. }\end{array}$ & $\begin{array}{l}\text { At Time } 1 \text {, care giving corresponded to } 12.4 \% \text { of } \\
\text { daily waking time; obligatory activities, } 52.4 \% \text {; } \\
\text { and discretionary activities, } 35.2 \% \text {. Those } \\
\text { performed by caregivers exclusively totaled } \\
46 \% \text {. A higher probability of institutionalization } \\
\text { and longer daily care time were associated with } \\
\text { providing more instrumental help, not working, } \\
\text { having a low income and co-residence. At Time } \\
2 \text {, institutionalization represented an increase in } \\
\text { one hour and } 47 \text { daily minutes of time invested in } \\
\text { discretionary activities by caregivers. }\end{array}$ \\
\hline $\begin{array}{l}\text { Clipp EC, } \\
\text { Moore MJ, } \\
\text { 1995. USA' }\end{array}$ & $\begin{array}{l}\text { To assess the } \\
\text { variations in care } \\
\text { time of formal and } \\
\text { informal caregivers } \\
\text { according to the } \\
\text { level of cognitive } \\
\text { deficit associated } \\
\text { with AD, due to the } \\
\text { administration of a } \\
\text { drug vs. placebo. }\end{array}$ & $\begin{array}{l}\text { A double-blind randomized clinical trial with } \\
441 \text { patients with Alzheimer's disease was } \\
\text { conducted, with two weeks of preparation, } 24 \\
\text { of treatment, six of discontinuing treatment, and } \\
\text { an undefined period of continued treatment. } \\
\text { The experimental group (EG) received } 150 \mathrm{mg} / \\
\text { day and } 225 \mathrm{mg} / \text { day of Velnacrine Maleate; } \\
\text { the control group (CG) received a placebo. } \\
\text { The cognitive functions of patients were tested } \\
\text { with the Alzheimer's Disease Assessment } \\
\text { Scale (ADAS). A total of } 160 \text { informal and } \\
\text { formal caregivers participated in the time use } \\
\text { measures at the baseline, in the 10th and 24th } \\
\text { week of treatment. Care time was assessed with } \\
\text { the Caregiver Activities Time Survey (CATS; }{ }^{\circledR} \\
\text { Hoechst-Roussel, 1990). }\end{array}$ & $\begin{array}{l}\text { The higher the cognitive impairment of } \\
\text { patients, the longer the time dedicated for } \\
\text { care. After } 24 \text { weeks of treatment with the } \\
\text { drug, there was a reduction of } 2.6 \text { hours/day } \\
\text { in the care time provided by family members } \\
\text { and friends; except for feeding, whose } \\
\text { time increased by } 8.7 \text { hours/day. The main } \\
\text { reductions in time for informal care were for } \\
\text { supervision ( } 2.1 \text { hours/day) and bathing ( } 36 \\
\text { minutes/day). The time spent on formal care } \\
\text { activities was not reduced with the treatment. }\end{array}$ \\
\hline
\end{tabular}




\begin{tabular}{|c|c|c|c|}
\hline $\begin{array}{l}\text { Authors, year } \\
\text { and country }\end{array}$ & Objective(s) & Design, participants, variables and measures & Results of interest \\
\hline $\begin{array}{l}\text { Davis KL, Marin } \\
\text { DB, Kane R, } \\
\text { Patrick D, } \\
\text { Peskind ER, } \\
\text { Raskind MA, } \\
\text { et al., } 1997 . \\
\text { USA } \\
\text { (20) }\end{array}$ & $\begin{array}{l}\text { To obtain evidence } \\
\text { on the test-retest } \\
\text { reliability and } \\
\text { concurrent validity } \\
\text { for the Caregiver } \\
\text { Activity Survey } \\
\text { (CAS) with family } \\
\text { caregivers. }\end{array}$ & $\begin{array}{l}\text { A methodological study was conducted } \\
\text { with } 42 \text { family caregivers. The Alzheimer's } \\
\text { Disease Assessment Scale - ADAS-cog, } \\
\text { Mini Mental State Exam (MMSE), Physical } \\
\text { Self Maintenance Scale (PSMS), and } \\
\text { Montegomery Burden Scale (MBS) were } \\
\text { applied six times (three times in the } 1 \text { st } \\
\text { week), none in the } 2 \text { nd week and three more } \\
\text { times in the } 3^{\text {rd }} \text { week. }\end{array}$ & $\begin{array}{l}\text { CAS showed a high level of test-retest } \\
\text { reliability }(0.88) \text { and high convergent validity } \\
\text { when compared to the ADAS-cog }(r=0.61) \text {, o } \\
\text { MMSE }(r=0.57) \text { and PSMS ( } r=0.43) \text {. } \\
\text { High significant correlation was found } \\
\text { between the number of hours of care and } \\
\text { scores of patients in the ADAS-cog, especially } \\
\text { for memory. Each extra point in the ADAS- } \\
\text { cog corresponded to an increase in } 15 \text { daily } \\
\text { minutes of care; and each extra point in the } \\
\text { ADAS-non-cog corresponded to } 25 \text { minutes. }\end{array}$ \\
\hline $\begin{array}{l}\text { Marin DB, } \\
\text { Dugue M, } \\
\text { Schmeidler } \\
\text { J, Santoro J, } \\
\text { Neugroschl J, } \\
\text { Zaklad G, et al., } \\
\text { 2000. EUA' }\end{array}$ & $\begin{array}{l}\text { To obtain evidence } \\
\text { on concurrent and } \\
\text { predictive validity } \\
\text { of the Caregiver } \\
\text { Activity Survey } \\
\text { (CAS) with five } \\
\text { items. }\end{array}$ & $\begin{array}{l}\text { A longitudinal study was conducted (one } \\
\text { year and six months) with } 18 \text { patients out of } \\
\text { an initial group of } 44 \text { who were followed by } \\
6 \text {-month visits. CAS and PSMS were applied to } \\
\text { caregivers and MMSE and ADAS were applied } \\
\text { to patients. }\end{array}$ & $\begin{array}{l}\text { There was an increase in } 2.8 \text { hours/day from } \\
\text { the first to the last measure, especially for } \\
\text { direct care and supervision. Throughout time, } \\
\text { CAS was significantly correlated to the MMSE, } \\
\text { ADAS-cog and PSMS. Care time increased with } \\
\text { the deterioration of elderly condition. As their } \\
\text { condition deteriorated, caregivers spent less } \\
\text { time communicating with them and more time } \\
\text { supervising them. }\end{array}$ \\
\hline $\begin{array}{l}\text { Stevens AB, } \\
\text { Coon D, } \\
\text { Wisniewski } \\
\text { S, Vance D, } \\
\text { Arguelles S, } \\
\text { Belle S, et al., } \\
\text { 2004. USA }\end{array}$ & $\begin{array}{l}\text { Psychometric } \\
\text { analysis of a } \\
\text { measure of } \\
\text { satisfaction with } \\
\text { leisure time among } \\
\text { family caregivers of } \\
\text { elderly with AD. }\end{array}$ & $\begin{array}{l}\text { Validation study with data on caregivers from } \\
\text { the Resources for Enhancing Alzheimer's } \\
\text { Caregiver Health (REACH), through which a } \\
\text { baseline measure and three follow-up measures } \\
\text { were performed, separated by six months. A } \\
\text { total of } 1,222 \text { caregivers were submitted to } \\
\text { the Leisure Time Satisfaction Scale - LTS (with } \\
\text { time for oneself,; to go to church and other } \\
\text { institutional meetings; for leisure activities; to } \\
\text { go to restaurants and social activities, to have } \\
\text { fun with others, and to visit family and friends), } \\
\text { CES-D and the Lubben Social Network Index. }\end{array}$ & $\begin{array}{l}\text { LTS achieved good internal consistency } \\
\text { (Cronbach } \alpha=0.80 \text { ); its one-factor structure } \\
\text { showed high levels of correlation with scales } \\
\text { of satisfaction with social support, relationship } \\
\text { network, and items from the sub-scale of well- } \\
\text { being of the CES-DS; negative correlations } \\
\text { between LTS and the time spent helping with } \\
\text { ADL and supervising. Good psychometric } \\
\text { properties were found in the validity and } \\
\text { internal reliability tests for LTS. }\end{array}$ \\
\hline $\begin{array}{l}\text { Feldman } \mathrm{HH}, \\
\text { Van Baelen B, } \\
\text { Kavanagh SM, } \\
\text { Torfs KE, 2005. } \\
\text { EUA, Canadá, } \\
\text { Europe }^{(23)}\end{array}$ & $\begin{array}{l}\text { To investigate } \\
\text { the relationships } \\
\text { between the } \\
\text { decrease in } \\
\text { cognition and } \\
\text { functionality in } \\
\text { ADL and the time } \\
\text { of care provided by } \\
\text { paid and unpaid } \\
\text { caregivers. }\end{array}$ & $\begin{array}{l}\text { A double-blind randomized clinical trial with an } \\
\text { EG (sabeluzol) and CG (placebo) was performed } \\
\text { during one year, including } 331 \text { patients with } \\
\text { moderate AD. Cognition was assessed with } \\
\text { the MMSE and ADS-cog, while ADLs were } \\
\text { assessed with the Disability Assessment in } \\
\text { Dementia (DAD). Care time was estimated } \\
\text { for each DAD domain: two weeks after each } \\
\text { of the assessments made with a questionnaire } \\
\text { (an initial measure and three more every three } \\
\text { months). }\end{array}$ & $\begin{array}{l}\text { There was a steady decrease in score in the } \\
\text { ADAS-cog and MMSE. After } 12 \text { months, } \\
\text { informal caregivers spent } 14 \text { more hours } \\
\text { every two weeks helping with BADLs. } \\
\text { Proportionately, formal care time increased } \\
\text { more than informal care time after one year, } \\
\text { varying from } 33+17 \text { hours to } 47+26 \text { hours } \\
\text { for every two weeks. }\end{array}$ \\
\hline $\begin{array}{l}\text { Van den Berg } \\
\text { B, Spauwen } \\
\text { P, 2006. } \\
\text { Australia }^{(24)}\end{array}$ & $\begin{array}{l}\text { To investigate the } \\
\text { validity of diaries } \\
\text { of time use in real } \\
\text { time and diaries } \\
\text { based on previous } \\
\text { day recall kept by } \\
\text { family caregivers. }\end{array}$ & $\begin{array}{l}\text { In this study, } 199 \text { family caregivers of } \\
\text { elderly with neurological, psychological and } \\
\text { neuromuscular problems completed two } \\
\text { types of "time vs. activity" diary: one in real } \\
\text { time, six times throughout the day, divided } \\
\text { into } 96 \text { periods of } 15 \text { minutes; and the other } \\
\text { based on "previous day recall + time matrix } \\
\text { vs. activities". Activities included support } \\
\text { for BADL (4) and IADL (6) and housework, } \\
\text { sleep, paid work and volunteer work. Up to } \\
\text { two simultaneous activities per interval were } \\
\text { recorded. }\end{array}$ & $\begin{array}{l}\text { When the normal housework time was } \\
\text { disregarded, care time lasted } 5.8 \text { hours/day } \\
\text { on average. Care activities performed jointly } \\
\text { overestimated caregivers' time by } 168 \text { hours/ } \\
\text { week. Previous day recall overestimated time } \\
\text { and showed lower stability in the test-retest } \\
\text { situation, compared to real time diaries. }\end{array}$ \\
\hline $\begin{array}{l}\text { Taylor DH Jr, } \\
\text { Kuchibhatla M, } \\
\text { Østbye T, } 2008 . \\
\text { USA }\end{array}$ & $\begin{array}{l}\text { To identify the } \\
\text { paths of care } \\
\text { provided by wives } \\
\text { to their husbands } \\
\text { with AD. }\end{array}$ & $\begin{array}{l}\text { A longitudinal study with data from } 828 \\
\text { women married to men who have AD, } \\
\text { derived from four annual surveys (1999-2002) } \\
\text { of the National Longitudinal Caregiver Study } \\
\text { (1999-2002). Data on time use obtained with } \\
\text { a questionnaire including } 22 \text { items that asked } \\
\text { about daily care activities and respective } \\
\text { durations at four different times. }\end{array}$ & $\begin{array}{l}\text { A total of three distinct paths of daily care time } \\
\text { were found, dependent on the development of } \\
\text { dementia: } 56.4 \% \text { of caregivers spent from } 252 \\
\text { minutes/day at the baseline to } 471 \text { minutes/ } \\
\text { day in the last measurement, } 30.3 \% \text { spent } \\
\text { from } 464 \text { minutes/day to } 533 \text { minutes/day, and } \\
13.3 \% \text { showed a reduction from } 719 \text { minutes/ } \\
\text { day to } 421 \text { minutes/day. }\end{array}$ \\
\hline
\end{tabular}




\begin{tabular}{|c|c|c|c|}
\hline $\begin{array}{l}\text { Authors, year } \\
\text { and country }\end{array}$ & Objective(s) & Design, participants, variables and measures & Results of interest \\
\hline $\begin{array}{l}\text { Neubauer S, } \\
\text { Holle R, Menn } \\
\text { P, Grossfeld- } \\
\text { Schmitz M, } \\
\text { Graesel, } \\
\text { E, 2008. } \\
\text { Germany }^{(26)}\end{array}$ & $\begin{array}{l}\text { To assess total } \\
\text { informal care time, } \\
\text { per week and per } \\
\text { day and to estimate } \\
\text { bias due to neglect } \\
\text { for the time of other } \\
\text { caregivers. }\end{array}$ & $\begin{array}{l}\text { A total of } 375 \text { caregivers participating in the } \\
\text { intervention study entitled Dementia Care } \\
\text { Initiative in Primary Practice, which lasted } \\
\text { two years, were submitted to an expanded } \\
\text { version of the Resource Utilization in Dementia } \\
\text { (RUD), asking about the number of days in the } \\
\text { previous four weeks and the number of hours } \\
\text { per day used to help patients with AD in IADLs } \\
\text { and BADLs and the number of hours spent } \\
\text { supervising them. }\end{array}$ & $\begin{array}{l}\text { The following were found: weekly means of } \\
42.8 \text { hours of BADLs, } 57.8 \text { hours of IADLs and } \\
52.5 \text { hours of supervision; } 47.6 \% \text { of daily time } \\
\text { spent in BADLs, } 64,6 \% \text { in IADLs and } 30.6 \% \text { in } \\
\text { supervision. Spouses and less healthy caregivers } \\
\text { cared for longer time. Of all elderly individuals, } \\
57 \% \text { had an informal caregiver, which would } \\
\text { lead to + } 14 \% \text { of distortion in the estimates of } \\
\text { time of primary caregivers if they were ignored. }\end{array}$ \\
\hline $\begin{array}{l}\text { Wimo A, } \\
\text { Jonsson L, } \\
\text { Zbrozek A, } \\
2010 . \\
\text { Sweden }^{(27)}\end{array}$ & $\begin{array}{l}\text { To analyze time use } \\
\text { measure validity, } \\
\text { based on the RUD, } \\
\text { among informal } \\
\text { caregivers of } \\
\text { elderly with AD. }\end{array}$ & $\begin{array}{l}\text { A prospective observational study was } \\
\text { performed with } 14 \text { patient-caregiver } \\
\text { pairs, married to each other, living in the } \\
\text { community, who produced } 47 \text { measures } \\
\text { of time based on two types of retrospective } \\
\text { measures (RUD and diary about previous day } \\
\text { recall of time use), which were compared to } \\
\text { data from direct observation ( } 30 \text { sessions). }\end{array}$ & $\begin{array}{l}\text { There was a high agreement between RUD and } \\
\text { the diaries about previous day recall, regarding } \\
\text { care in BADL (ICC }=0.93 \text { ), supervision (ICC } \\
=0.87) \text { and total care time (ICC }=0.91 \text { ) and } \\
\text { IADL (ICC }=0.75 \text { ). The ICCs between direct } \\
\text { observation and RUD were as follows: BADL, } \\
\text { ICC }=0.81 \text {; IADL, ICC }=0.74 \text {; supervision, ICC } \\
=0.78 \text { and total time, ICC }=0.80 \text {. }\end{array}$ \\
\hline $\begin{array}{l}\text { Shahly V, } \\
\text { Chatterji S, } \\
\text { Gruber MJ, } \\
\text { Al-Hamzawi } \\
\text { A, Alonso J, } \\
\text { Andrade LH, et } \\
\text { al., 2013. USA } \\
\text { and 22 other } \\
\text { countries }^{(28)}\end{array}$ & $\begin{array}{l}\text { To analyze the } \\
\text { objective and } \\
\text { subjective burden } \\
\text { associated with } \\
\text { health problems } \\
\text { in the family, } \\
\text { family support } \\
\text { and vulnerability } \\
\text { of caregivers to } \\
\text { objective and } \\
\text { subjective burden. }\end{array}$ & $\begin{array}{l}\text { An observational epidemiological study was } \\
\text { conducted in } 20 \text { countries/members of the World } \\
\text { Health Organization (WHO), divided according } \\
\text { to the level of income of the population. A total } \\
\text { of } 13,892 \text { informal caregivers aged } 50 \text { years and } \\
\text { older responded to a questionnaire (developed } \\
\text { for this study) about the objective burden (time } \\
\text { and money) and subjective burden (suffering } \\
\text { and shame) associated with providing informal } \\
\text { care to } 1 \text { st degree relatives with severe physical } \\
\text { and mental health conditions. In each country, } \\
\text { the differential burden was analyzed according } \\
\text { to income level, kinship, and type of health } \\
\text { condition. }\end{array}$ & $\begin{array}{l}\text { The mean number of hours of care varied from } \\
16.6 \text { to } 23.6 / \text { week. From } 26.9 \% \text { to } 42.5 \% \text { of } \\
\text { caregivers had } 1 \text { st degree relatives with serious } \\
\text { health problems; from } 35.7 \% \text { to } 42.5 \% \text { reported } \\
\text { objective and subjective burden. Of the total } \\
\text { number, between } 25.2 \% \text { and } 29.0 \% \text { had burden } \\
\text { of time; between } 13.5 \% \text { and } 19.4 \% \text { had financial } \\
\text { burden; between } 24.4 \% \text { and } 30.6 \% \text {, suffering; } \\
\text { and between } 6.4 \% \text { and } 21.7 \% \text {, shame. In } \\
\text { low-income and middle-income countries, the } \\
\text { financial burden was two to three times higher } \\
\text { than that of high-income countries. Wives and } \\
\text { daughters reported more burden than other } \\
\text { women without family ties to those receiving care. }\end{array}$ \\
\hline $\begin{array}{l}\text { Haro JM, Kahle- } \\
\text { Wrobleski K, } \\
\text { Bruno G, Belger } \\
\text { M, Dell'Agnello } \\
\text { G, Dodel R, et } \\
\text { al., 2014. } \\
\text { France, } \\
\text { Germany } \\
\text { and United } \\
\text { Kingdom }^{(29)}\end{array}$ & $\begin{array}{l}\text { To characterize } \\
\text { caregivers of } \\
\text { elderly in the } \\
\text { community, } \\
\text { according to the } \\
\text { severity of AD of } \\
\text { patients, and to } \\
\text { identify factors } \\
\text { associated with } \\
\text { perceived burden } \\
\text { and care time. }\end{array}$ & $\begin{array}{l}\text { In this study, 1,497 primary informal } \\
\text { caregivers of patients with AD recruited } \\
\text { in the community, divided by gender, } \\
\text { co-residence, being a spouse, working, } \\
\text { comorbidities and suffering, according to } \\
\text { patients' psychiatric symptoms, in the context } \\
\text { of the GERAS study on costs and resources } \\
\text { for AD care, responded to Zarit's scale of } \\
\text { perceived burden and the RUD, during } \\
\text { the month prior to the visit for the baseline } \\
\text { measurements. }\end{array}$ & $\begin{array}{l}\text { There was an increase in the severity of AD } \\
\text { associated with the increase in burden and care } \\
\text { time. The higher the level of dependence on } \\
\text { IADL, the greater the severity of AD and burden. } \\
\text { Co-residence, being male, living in a rural } \\
\text { area, apathy and psychosis in patients, medical } \\
\text { emergencies, not receiving food at home, and } \\
\text { receiving financial support to provide care } \\
\text { were associated with longer time dedicated to } \\
\text { supervision. Burden was associated with younger } \\
\text { age and depression of caregivers, caring for male } \\
\text { patients and providing care for longer time. }\end{array}$ \\
\hline $\begin{array}{l}\text { Hughes TB, } \\
\text { Black BS, Albert } \\
\text { M, Gitlin LN, } \\
\text { Johnson DM, } \\
\text { Lyketsos CG, } \\
\text { et al., 2014. } \\
\text { USA }^{(30)}\end{array}$ & $\begin{array}{l}\text { To analyze the } \\
\text { relationship of } \\
\text { unmet dementia- } \\
\text { related care needs } \\
\text { of community } \\
\text { dwelling } \\
\text { individuals, and } \\
\text { their caregivers } \\
\text { to measures of } \\
\text { caregiver burden. }\end{array}$ & $\begin{array}{l}\text { A total of } 254 \text { community elderly with AD } \\
\text { and their caregivers (246), who responded } \\
\text { to the Zarit's scale of perceived burden and } \\
\text { the Johns Hopkins Dementia Care Needs } \\
\text { Assessment, were selected from the database } \\
\text { of this study. Elderly individuals were } \\
\text { submitted to the Psychogeriatric Dependency } \\
\text { Rating Scale (PDRS). Objective burden was } \\
\text { indicated by the weekly hours of care and } \\
\text { absence from work. }\end{array}$ & $\begin{array}{l}\text { A total of } 27 \% \text { of variance of care time could } \\
\text { be explained by the following: being the } \\
\text { caregiver of the spouse, not having respite } \\
\text { care, being employed, patient's functional } \\
\text { dependence, lack of specialized medical } \\
\text { care, caregiver's education, and patients' } \\
\text { neuropsychiatric disorders. Every five points } \\
\text { added to the PDRS score led to an increase of } \\
54 \% \text { in caregivers' risk of loss of eight or more } \\
\text { hours/week of work. }\end{array}$ \\
\hline $\begin{array}{l}\text { Kraijo H, van } \\
\text { Exel J, Brouwer } \\
\text { W, } 2015 \text {. } \\
\text { Holland }^{(31)}\end{array}$ & $\begin{array}{l}\text { To investigate for } \\
\text { how long informal } \\
\text { caregivers of } \\
\text { elderly with AD } \\
\text { can be expected } \\
\text { to persevere to } \\
\text { provide care. }\end{array}$ & $\begin{array}{l}\text { A total of } 198 \text { caregivers of } 198 \text { patients with } \\
\text { AD were included in a longitudinal cohort } \\
\text { study. MMSE, ADAS, and measures of ADL } \\
\text { functionality and neuropsychiatric disorders } \\
\text { were applied to patients. Zarit's burden } \\
\text { inventory, the measure of suffering due to } \\
\text { patients' neuropsychiatric symptoms, the } \\
\text { RUD and one item about perseverance time } \\
\text { (PT) were applied to caregivers. }\end{array}$ & $\begin{array}{l}\text { After one year, } 74 \text { elderly individuals were still } \\
\text { living at home, and after two years, } 44 \text {. The } \\
\text { remaining ones were either institutionalized or } \\
\text { dead. Care time at the baseline was } 3.2 \text { days/ } \\
\text { week and } 38.6 \text { hours/month. The more severe the } \\
\text { AD, the longer the time of care and supervision. } \\
\text { There was a low correlation between burden and } \\
\text { PT: } 6.1 \% \text { with PT }>1 \text { week and }<1 \text { month; } \\
14.65 \% \text {, PT }>1 \text { month and }<6 \text { months; } 19.7 \% \text {, } \\
\text { PT }<6 \text { months and }<1 \text { year, and } 39.9 \%, \text { PT }=2 \\
\text { years. After one year, } 37.4 \% \text { still provided care at } \\
\text { home; after two years, } 22.2 \% \text {. }\end{array}$ \\
\hline
\end{tabular}




\begin{tabular}{|c|c|c|c|}
\hline $\begin{array}{l}\text { Authors, year } \\
\text { and country }\end{array}$ & Objective(s) & Design, participants, variables and measures & Results of interest \\
\hline $\begin{array}{l}\text { Hajek A, } \\
\text { Brettschneider } \\
\text { C, Ernst A, } \\
\text { Posselt T, Wiese } \\
\text { B, Prokein J, } \\
\text { et al., 2016. } \\
\text { Germany }^{(32)}\end{array}$ & $\begin{array}{l}\text { To investigate } \\
\text { the predictors of } \\
\text { time of informal } \\
\text { and formal care } \\
\text { provided to } \\
\text { patients living in } \\
\text { the community, } \\
\text { considering the } \\
\text { severity of AD. }\end{array}$ & $\begin{array}{l}\text { The caregiving time for } 126 \text { community- } \\
\text { dwelling } \\
\text { AD patients was assessed at 6-month intervals, } \\
\text { in a } 1.5 \text { years of longitudinal follow-up from } \\
\text { the German Study on Ageing, Cognition and } \\
\text { Dementia in Primary Care Patients (Age-CoDe). } \\
\text { Formal and informal caregivers responded } \\
\text { to CDR (Clinical Dementia Rating), GDS } \\
\text { (Global Deterioration Scale) and RUD. Patients } \\
\text { responded to the MMSE, Barthel Index and } \\
\text { Lawton and Brody's scale of IADL. Formal care } \\
\text { time included nursing outpatient care, home } \\
\text { care, shopping and the presence of a private } \\
\text { caregiver. }\end{array}$ & $\begin{array}{l}\text { A total of } 43 \text { patients had very mild dementia; } 55 \text {, } \\
\text { mild; and } 28 \text {, from moderate to severe. The mean } \\
\text { time of informal care was } 2.3 \mathrm{~h} \pm 3.4 \text { hours/ } \\
\text { day, and that of formal care, } 1.2 \mathrm{~h} \pm 2.4 \text { hours/ } \\
\text { day. The severity of AD, being a spouse and } \\
\text { patients' age affected the total time of informal } \\
\text { care. The severity of AD did not affect formal care } \\
\text { time. Spouses spent more time in all categories } \\
\text { of informal care, except for appointment and } \\
\text { financial management. }\end{array}$ \\
\hline $\begin{array}{l}\text { Oldenkamp M, } \\
\text { Hagedoorn M, } \\
\text { Slaets J, Stolk } \\
\text { R, Wittek R, } \\
\text { Smidt N. 2016. } \\
\text { Holland }^{(33)}\end{array}$ & $\begin{array}{l}\text { Investigate (a) the } \\
\text { extent to which } \\
\text { spousal and } \\
\text { adult-child } \\
\text { caregivers of highly } \\
\text { dependent older } \\
\text { Dutch differ in their } \\
\text { subjective burden, } \\
\text { and (b) the correlates } \\
\text { of overall subjective } \\
\text { burden and multiple } \\
\text { subjective burden } \\
\text { dimensions among } \\
\text { spousal and adult- } \\
\text { child caregivers at } \\
\text { one time point } \\
\text { and over a 12-month } \\
\text { period. }\end{array}$ & $\begin{array}{l}\text { A longitudinal study was conducted. At the } \\
\text { baseline, } 356 \text { elderly individuals and their } \\
\text { caregivers ( } 43 \% \text { of which were spouses and } \\
57 \% \text {, sons and daughters) were selected } \\
\text { among } 505 \text { participants from } 25 \text { services; } \\
158 \text { caregivers ( } 44 \% \text {, spouses) participated of } \\
\text { the follow-up. Burden was indicated by the } \\
\text { caregivers scores in the Care-Related Quality } \\
\text { of Life Instrument (CarerQoL-7D); number } \\
\text { of hours of household care, personal care } \\
\text { and practical care, and health conditions of } \\
\text { care recipients (multimorbidity, functional } \\
\text { limitations in IADL and BADL, and cognitive } \\
\text { problems). }\end{array}$ & $\begin{array}{l}\text { According to the two measures, spouses scored } \\
\text { higher for perceived burden, and reported } \\
\text { more mental and physical health problems } \\
\text { associated with care in ADL than sons/ } \\
\text { daughters. The worse the health conditions } \\
\text { of those receiving care, the higher the burden } \\
\text { perceived by spouses. Among sons/daughters, } \\
\text { the perceived burden was associated with } \\
\text { longer care time. Subjective burden at } \\
\text { follow-up was mainly explained by baseline } \\
\text { subjective burden. }\end{array}$ \\
\hline $\begin{array}{l}\text { Vaingankar } \\
\text { JA, Chong } \\
\text { SA, Abdin } \\
\text { E, Picco L, } \\
\text { Jeyagurunathan } \\
\text { A, Zhang Y, et } \\
\text { al., 2016. } \\
\text { Singapor } \\
\text { e }^{(34)}\end{array}$ & $\begin{array}{l}\text { To investigate the } \\
\text { participation of } \\
\text { care, needs and } \\
\text { burden of care in a } \\
\text { cohort of informal } \\
\text { caregivers of the } \\
\text { elderly. } \\
\text { To describe the } \\
\text { participation of } \\
\text { informal caregivers } \\
\text { of elderly with } \\
\text { any care needs; to } \\
\text { investigate } \\
\text { differences in } \\
\text { time and type of } \\
\text { care according to } \\
\text { dementia status of } \\
\text { the care receivers, } \\
\text { and to examine } \\
\text { correlates of } \\
\text { caregivers' burden. }\end{array}$ & $\begin{array}{l}\text { In a population-based study carried out in } \\
\text { Singapore, } 693 \text { pairs of elderly individuals } \\
\text { aged } 60 \text { to } 100 \text { years, having any care needs, } \\
\text { and their informal caregivers aged } 21 \text { to } 88 \\
\text { years, were interviewed during a cross- } \\
\text { sectional national survey. Data on behavioral } \\
\text { and psychological symptoms of dementia, } \\
\text { dementia diagnosis, care needs, and socio- } \\
\text { demographic characteristics of the care } \\
\text { receivers were obtained. The Zarit's burden } \\
\text { scale was applied to caregivers. Time use } \\
\text { was assessed with questions about how many } \\
\text { hours per day (from }<1 \text { to } 2 \text { hours) were } \\
\text { spent on care in eight ADLs. }\end{array}$ & $\begin{array}{l}\text { Among the elderly with any care need, } \\
356(51.4 \%) \text { had dementia. Caregivers' } \\
\text { participation was highest in activities related to } \\
\text { communication }(35.1 \%) \text {, feeding } \\
(32 \%) \text {, and bathing }(21.1 \%) \text {. Caregiving } \\
\text { burden was significantly associated with being } \\
\text { caregiver of a spouse, being caregiver of the } \\
\text { youngest olds, provide care much of the time, } \\
\text { care provided to individuals with behavioral } \\
\text { and psychiatric symptoms of dementia, and } \\
\text { having dementia diagnosis. }\end{array}$ \\
\hline
\end{tabular}

Note: ADL - Activities of Daily Living; BADL - Basic Activities of Daily Living; IADL - Instrumental Activities of Daily Living; ICC - Intraclass Correlation Coefficient; $A D$ - Alzheimer's Disease; MMSE - Mini Mental State Exam; PSMS - Physical Self Maintenance Scale

Of all 17 articles selected ${ }^{(12,19-34)}$, five are of a psychometric nature and aim to derive indicators of validity of self-reported measures, compared to objective measures of time use $\mathrm{e}^{(20-}$ $22,24,27)$; one ${ }^{(19)}$ is a randomized double-blind clinical study in which the independent variable was a drug versus placebo administered to elderly with dementia and the dependent variable was time use by caregivers. Two are of a methodological nature $^{(12,26)}$ and, although not being psychometric studies, they contribute to the construction and improvement of instruments for time use measures. One of them is longitudinal ${ }^{(25)}$, with repeated measures of time use throughout the development of the disease among the elderly under care; and the other one is prospective ${ }^{(32)}$. A total of seven articles are correlational and describe time use patterns considered to be indicators of the objective and subjective burden of care, interacting with other variables of the context of care $^{(23,28-31,33-34)}$. 
Although the differences between raw values of time dedicated to obligatory activities were significant, the studies analyzed showed that time spent on care is longer for informal caregivers than for formal caregivers ${ }^{(24,33)}$, for spouses than for those who are not spouses of elderly receiving care ${ }^{(28,30,32-33)}$, for those living with individuals who receive care ${ }^{(12)}$, for lowincome caregivers $^{(12)}$, for those who have health problems ${ }^{(26,33)}$, for those who rely on more than one caregiver ${ }^{(26)}$ and for those who have less information about how to care, have little access to specialized medical care and reduced experience concerning the management of psychiatric and behavioral disorders associated with dementia ${ }^{(28,30-31)}$. There was an inverse relationship between time dedicated to care and the level of

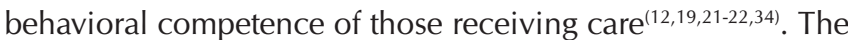
time dedicated to obligatory activities is spent on support for IADLs and BADLs and on supervision when dealing with behavioral problems associated with dementia ${ }^{(20,22,28,30,32,34)}$. The increase in the number of hours dedicated to care, especially time for supervision, is also associated with the development of dementia ${ }^{(21-22,25-26,32-34)}$ and advance in age of those receiving care $^{(32)}$. Obligatory activities of care are the ones that consume the most waking time of caregivers ${ }^{(12,19,24,27,32,34)}$, who tend to show dissatisfaction with the insufficient time spent on social activities and the insufficient time they have for themselves ${ }^{(23)}$. When released from obligatory activities, they tend to allocate the time that used to be spent on obligatory activities for discretionary activities, especially social ones performed outdoors $^{(12)}$. Restriction to participation in leisure activities is a source of dissatisfaction, depressive symptoms and assessment of lack of social support ${ }^{(22)}$. The higher the number of hours spent on care, the higher the number of missed hours of paid work out of home ${ }^{(30)}$. Care tasks performed together lead to an overestimation of hours of care ${ }^{(24)}$ and the disregard for the presence of secondary caregivers results in a distortion in the estimates of time of primary caregivers ${ }^{(26)}$.

The studies selected used three types of measure of time use by caregivers. One was the direct observation of occurrence and the duration of care activities ${ }^{(27)}$, considered to be the most objective measure and the gold standard in studies on validation of measures of self-reported time use ${ }^{(27)}$. Among the verbal measures used, there were two that included a matrix to record time estimates per activity. One measure involved real-time records of activities performed during each of the 15-minute intervals, made by caregivers six times a day. These intervals were marked on the "time vs. activity" matrix (24). The other measure was calculated in the same matrix, which, however, was not completed in real time by caregivers, but rather by the interviewer, at their sight, asking about their estimates of time vs. activity throughout the previous day (yesterday interview) $)^{(12,24,27)}$.

In addition to the time vs. activity matrices, research on time use by caregivers included activity vs. time inventories $^{(19,21-22,26-27,29,31-32)}$, activity lists ${ }^{(33)}$, questionnaires ${ }^{(22-23,25)}$ and interviews ${ }^{(28,33-34)}$. These three last methodological resources are based on their memories of activities and respective duration on the previous day or week. As an example, the questionnaire developed by Stevens et al. (2004) (22) included items about how long individuals receiving care can be left alone at home in a room, how long caregivers think they should be present and for how many hours they should perform care tasks of ADL; while that of Vaingankar et al. (2016) was based on a list of eight care activities ${ }^{(34)}$.

Inventories of care activities performed on the previous day or during one or more previous weeks are measures validated by comparison with others based on direct observation or in time vs. activity matrices ${ }^{(27)}$. A total of three inventories were used in studies published during the period covered by this review: the Caregiver Activities Time Survey (CATS) ${ }^{(19)}$, the Caregiver Activities Scale (CAS) ${ }^{(21-22)}$ and the Resource Utilization in Dementia (RUD) ${ }^{(26-27,29,31-32)}$.

The CATS was validated in a study that tested the long term effects of a drug aimed at controlling signs and symptoms of Alzheimer's disease ${ }^{(19)}$. It includes formal care activities (nursing visits, health care support, services, home services, meals on wheels, daily care programs and transport). It asks how many times the service was offered in the previous two weeks and the mean time of visits in hours and minutes. The survey with informal caregivers included activities such as feeding, toilet, bathing, dressing, drug administration, supervision, home care, and transport. Additionally, it asks about the duration of activities throughout a typical day and week.

The CATS is comprised of five items that assess the amount of time caregivers spend on a typical day, performing the following tasks: supervision, communication, dressing, feeding, caring for the patient's appearance, and transport. This scale was submitted to psychometric analysis in the studies performed by Davis et al. (1997)(20) and Marin et al. (2000) ${ }^{(21)}$.

The RUD was developed for the study on the relationship between cost and effectiveness of care for elderly with dementia. Time is one of the resources assessed by the inventory, which focuses on informal care for (a) personal needs and basic activities such as feeding, dressing, taking a shower/bath, and mobility; (b) IADL, such as cooking, shopping, housework, finance management, using a telephone, driving or using other types of transport, and (c) supervision (aimed at preventing dangerous accidents indoors and outdoors, protecting individuals against aggressive attacks from elderly with dementia, and managing inappropriate behavior such as urinating on the floor and using offensive language). Moreover, it assesses the use of formal resources such as home care, hospitalization days and number of visits to specialized services. Finally, it asks how many days during the previous month and, on these days, how many hours on average primary informal caregivers provided care to patients or formal care was received ${ }^{(26-27,29,31-32)}$.

Revealing the importance attributed to the validity of measures, five out of the 17 articles selected $^{(20-22,24,27)}$ are psychometric studies on instruments to measure time use by caregivers of elderly with dementia. According to reports, estimates of time collected with the yesterday interview, based on the matrix of activities in 15-minute intervals, were found to be more reliable and stable than the data obtained with the completion of the lists of activities from the previous week ${ }^{(25)}$. According to the Alzheimer's Disease Assessment Scale, Mini Mental State Exam and Physical Maintenance Scale, the scores obtained by individuals receiving care had a significantly high 
correlation with the number of hours informed by caregivers, with both observational(21) and longitudinal designs ${ }^{(22)}$. High levels of agreement were found between retrospective measures of time use, based on the RUD and measures resulting from the direct observation of caregivers' behavior, and between data from the RUD and from the matrix of activities in 15-minute intervals ${ }^{(28)}$. There was good evidence of internal validity and the construct for a scale of caregivers' satisfaction with the time spent on leisure, but only moderate correlations with satisfaction with social support ${ }^{(23)}$.

As indicators of perceived or subjective burden associated with care, the following aspects were analyzed: depression ${ }^{(30)}$, perceived burden ${ }^{(29-31,33-34)}$, caregivers, suffering due to neuropsychiatric symptoms presented by individuals receiving care $^{(30,32)}$, health problems self-reported by caregivers ${ }^{(33)}$ and caregivers' unfulfilled needs ${ }^{(30)}$. In these studies, the following were considered to be objective burden: time use by caregivers, physical and cognitive competence, and neuropsychiatric problems of elderly receiving care. Caregivers' suffering associated with neuropsychiatric symptoms of elderly receiving care and perceived burden was particularly connected to the time spent on supervi$\operatorname{sion}^{(30-32)}$. The more severe the dementia of those being cared for, the longer the perseverance time in caregivers' role and the greater their perceived burden ${ }^{(32)}$. The unfulfilled needs that accounted for the greater variability in care time were as follows: financial support, food delivered at home ${ }^{(30)}$, caregivers available to work on the days or time off of main caregivers, access to specialized medical services, and caregivers' education for the practice of care $^{(31)}$. In the five studies, there were relationships between objective measures of burden of care and the perception of subjective burden reported by caregivers.

\section{DISCUSSION}

Care for the elderly who have difficulties to perform activities of daily living independently and who show neuropsychiatric problems determined by the development of dementia in a moderate or advanced stage exemplifies the complex conditions and high demand faced by family caregivers and offers parameters to understand other aspects of family care for elderly with different health conditions. For these reasons, this was one of the conditions chosen for the selection of articles found in the present review.

The analysis of articles enabled the conclusion that there is an important gap in terms of data on time spent on care tasks performed at the same time or together with caregivers' house and personal chores; as well as on the duration, frequency and nature of the tasks performed concurrently by other family members and professional caregivers. This gap is important in countries that rely on a good formal support network for elderly with dementia, as it disguises information about the objective and subjective burden and the unfulfilled needs of family caregivers. This is even more important in Brazil, a country that relies on a poor network of formal care for dependent and ill elderly. Moreover, housemaids are part of our society, who, in addition to performing house chores, are also very likely to care for the elderly. There is an ingrained culture of attributing care tasks to these professionals as if this were an extension of house chores ${ }^{(17)}$.

Less involved affectively, without a previous history of relationship and physically more distant from the routine of care, formal or professional caregivers do not suffer from the same difficulties as family caregivers and spend less time providing care than the latter ${ }^{(19,23,32)}$. Thus, to find out how they manage their care activities in their work schedule provides parameters to assess the investment in time and effort of family caregivers. The fact that formal caregivers are also subject to work burden helps to understand that which affects family caregivers. The discussion about these aspects from the economic point of view, not only from the perspective of subjectivity, is important at this moment when the question about the creation of the older adult caregiver profession and occupation is being debated in Brazil(28).

In the international literature, the physical and psychological burden of family caregivers of elderly with dementia is highly relevant, compared to that of individuals caring for elderly with limitations determined by other health conditions. Data resulting from studies on time use by family caregivers of elderly with dementia are compatible with the vast empirical and theoretical literature on caregivers, stress, which has been developed since the $1980 \mathrm{~s}^{(35-36)}$. This is reflected in Brazil ${ }^{(37)}$, although, as it happens with other themes, there is neither a systematic and good scientific production here, nor studies on time use by caregivers. Data on demonstrative and methodological research developed in other countries may be sufficiently general to enable Brazilian researchers to shorten the time spent on this line of research, during the period when, for the purpose of this review, publications by Moss et al.(1993) $)^{(12)}$ and Wimo, Jonsson and Zbrozek (2010) (27) stood out. The combination of the theme of objective and subjective burden and their effects on caregivers, as observed in the articles published between 2013 and 2016 ${ }^{(28-34)}$, is a useful foundation for promising lines of research that meet our needs for information. Perhaps this can help to prevent the following question posed by Camarano in $2010^{(17)}$ from being answered affirmatively - Is care a new social risk to be assumed in Brazil? - to which we would add: (...) by families and family caregivers, as most of their needs are not met?

The weight of care on the subjective well-being and health of family caregivers of dependent elderly is associated with objective physical burden connected to tasks supporting IADLs and BADLs and to the time spent on care. It is also associated with the perceived or psychological burden resulting from the experience of suffering and unfulfilled needs, although it is not restricted to this. Furthermore, it is associated with the fact that care for such elderly is a task that unfolds in the daily time, individual time and family time, competing with work, social participation, and family commitments to care ${ }^{(23,28-29,32-33)}$. Care can hinder family relationships, friendships and religious, cultural and recreational activities. It can also contribute to caregivers delaying or abandoning activities of self-care for health and appearance. Moreover, it interacts with pre-existing morbid conditions or those appearing after the beginning of care. Finally, it hinders leisure activities and opportunities of rest for individuals involved with the tasks and role of caregivers. Informal caregivers with chronic diseases spend more time caring for their own health, compared to those not providing 
care, although they spend more time caring for the health of elderly than their own. This means that, to a certain extent, there is an incompatibility between the responsibilities for the care of an older family member and the maintenance of health by caregivers who are old and fragile $\mathrm{e}^{(38)}$.

In the care process, the compulsory replacement of activities and personal, work, social life and family life routines, over which caregivers had control and obtained benefits, for other activities determined by the care dynamics causes changes to their daily routine and perspective of personal time. It is as if the time dedicated to care was a time subtracted from that previously available for caregivers or as if the sense of freedom of choice of caregivers was harmed ${ }^{(38)}$. To a great extent, the sense of burden and invasion of one's personal life experienced by family caregivers of elderly with severe physical and cognitive dependence can be attributed to such perceptions. This is a time whose duration is assessed by caregivers, compared to the duration of other liked, disliked or neutral tasks, depending on the objectives, products and attributed value ${ }^{(39)}$.

In conclusion, it is important to note that time is not an entity existing in real life. The notions of objective and subjective time are variants of the same construct that finds their foundation on human activities, needs, affections and motivations. For this reason, the understanding of and interventions in time use by caregivers of elderly with dementia can greatly benefit from the concept of time use as routine management; management being the activities of planning, performing, monitoring, and assessing actions aimed at one objective; and routine being the time and place where routines, habits and the organization of personal and family life occur. Thus, to plan care time use means to plan the routines of such undertaking. It involves the establishment of priorities, the decision about the level of investment in tasks and the acquisition of resources to achieve this. Routine management, or care time management, helps caregivers to be organized, to have the feeling of continuity in life, to maintain the sense of control, and to feel safe regarding the tasks performed on a daily basis. Additionally, such management helps them organize their work schedules, including the obligatory routines of care provision, the obligatory routines of their own daily life, and the routine of elective or discretionary activities of their personal, family and social life, considering the opportunities and obstacles of the environmental and social contexts in which they are performed.

Despite the advances in the literature on time use by family caregivers of the elderly, there are few studies that discern care tasks performed independently from others performed simultaneously. Likewise, there are few studies on time use by primary caregivers, when there are secondary caregivers involved. The relationships between time use and quality of care is another gap found in the literature analyzed.

\section{Limitations of study}

The MEDLINE/PubMed and BVS/LILACS/SciELo databases are well known for their inclusive, reliable and effective nature in the cataloging and continuous availability of international scientific production in the areas of Medicine, Life Sciences and Health Sciences. For this reason, they were selected as the primary means to obtain the information required for the present study. On the other hand, the restriction was partly due to the need to adapt the corpus to the limits of space of periodicals. New studies will be able to use other international databases, such as those in Psychology (PsycINFO) and Social Sciences (AgeLine), seeking information that may have not been published in the databases selected for this study.

\section{Contributions to the area of nursing and public health}

We expect that the knowledge produced by the present investigation on time use and promoted by this review can help Brazilian health care professionals to obtain useful data and make decisions about the implementation of psychosocial support and educational programs focused on the organization of care, personal life, family life and social life activity schedules for family caregivers.

\section{FINAL CONSIDERATIONS}

There are three principles that can be extracted from the literature on time use by family caregivers of elderly with dementia, published between 1993 and 2017. The first principle is that the life of elderly individuals and that of elderly family caregivers with dementia involves daily routines of observable, regular and repetitive behavioral patterns with a predetermined sequence and duration. These routines are based on an ecological context that includes physical and material conditions for their occurrence and on a cultural context that gives them meaning and value. The second principle is that the care routine includes two intertwined routines: that of elderly receiving care and that of family members providing such care. Finally, the third principle is that the physical and cognitive independence and health conditions of elderly receiving care are important determinants of objective burden and the number of daily hours dedicated to informal care in the family context.

The absolute values found in the literature on time use in health care for elderly with dementia are highly variable, reflecting the influence of the methodology used to obtain data, the willingness of caregivers to respond to questionnaires, their socioeconomic level mirrored in the resources available for care provision, the level of cognitive and physical dependence of those receiving care and their needs for supervision associated with neuropsychiatric disorders. Due to the discrepancies among data on time use by caregivers, methodological studies that provide information about the most stable and reliable measures are important resources to help researchers to make decisions.

The study on time use by informal and formal caregivers of elderly is practically inexistent in Brazil. This condition provides usefulness and opportunity for studies on literature review, as they synthesize multiple evidence of studies performed in different contexts, provide knowledge about the phenomenon and methodological resources to better understand and control it, facilitate the identification of gaps of information, and can guide one to make decisions about the establishment of lines of research about the theme. Additionally, they can contribute to the planning of interventions focused on the management of health care activities by family caregivers, considering their personal, family and social resources, needs and motivations. 


\section{REFERENCES}

1. Beyer GW, Woods ME. Living and activity pattems of the aged. Wadsworth: Cornell University Centre for Housing and Enviromental Studies; 1963.

2. Havighurst RJ, Neugarten B, Tobin S. Disengagement and patterns of aging. In: Neugarten BL. (Ed.). Middle Age and Aging. Chicago: University of Chicago; 1969.

3. Gauthier AH, Smeeding TM. Time use at older ages: cross-national differences. Res Aging [Internet]. 2003 [cited 2017 May 2];25(3):247-74. Available from: http://journals.sagepub.com/doi/abs/10.1177/0164027503025003003

4. Chapin FS. Human Activity in the City. Toronto: John Wiley; 1974.

5. Lawton MP, Brody EM, Turner-Massey P. The relationships of environmental factors to changes in well-being. Gerontol[Internet]. 1978 [cited 2017 May 1];8(2):133-7. Available from: https://www.ncbi.nlm.nih.gov/pubmed/640453

6. Moss MS, Lawton MP. Time budgets of older people: a window on four life styles. J Gerontol [Internet]. 1982 [cited 2017 May 1];37(1):115-23. Available from: https://www.ncbi.nlm.nih.gov/pubmed/7053392

7. Klumb PL, Baltes MM. Time use of old and very old Berliners: productive and consumptive activities as functions of resources. J Gerontol B Psychol Sci Soc Sci [Internet]. 1999 [cited 2016 Apr 22];54(5):S271-8. Available from: https://www.ncbi.nlm.nih.gov/ pubmed/10542829

8. Baltes MM, Wahl HW, Schmid-Furstoss U. The daily life of elderly Germans: activity patterns, personal control, and functional health. J Gerontol [Internet]. 1990 [cited 2017 May 1];45(4):P173-9. Available from: https://www.ncbi.nlm.nih.gov/pubmed/2365973

9. Klumb PL, Baltes MM. Validity of retrospective time-use reports in old age. Appl Cognit Psychol [Internet]. 1999 [cited 2017 May 2];13:52739. Available from: http://onlinelibrary.wiley.com/doi/10.1002/(SICI)1099-0720(199912)13:6\%3C527::AID-ACP614\%3E3.0.CO;2-1/epdf

10. Pruchno RA, Rose MS. Time use by frail older people in different care settings. J Appl Gerontol [Internet]. 2002 [cited 2017 May 1];21:5-23. Available from: http://journals.sagepub.com/doi/abs/10.1177/0733464802021001001

11. Lawton MP, Moss M, Fulcomer M. Objective and subjective uses of time by older people. Int J Aging Hum Dev [Internet]. 19861987 [cited 2017 May 1];24(3):171-88. Available from: https://www.ncbi.nlm.nih.gov/pubmed/ 3596823

12. Moss MS, Lawton MP, Kleban MH, Duhamel L. Time use of caregivers of impaired elders before and after institutionalization. J Gerontol [Internet]. 1993 [cited 2016 Apr 22];48(3):S102-11. Available from: https://www.ncbi.nlm.nih.gov/pubmed 8482826

13. Doimo LA, Derntl AM, do Lago OC. [Time use in the daily life of aged women: an indicative method of the life style of population groups]. Cienc Saude Colet [Internet]. 2008 [cited 2016 Apr 22];13(4):1133-42. Available from: https://www.ncbi.nlm.nih.gov/ pubmed/18813612 Portuguese.

14. Santos ARM, Cartaxo HGO, Silva EAPC, Moura PV, Freitas CMM. Usando o tempo a favor do bem-estar: uma configuração do estilo de vida dos idosos. Estud Interdiscipl Envelhec [Internet]. 2013 [cited 2017 May 1];18(1):27-43. Available from: http://www. seer.ufrgs.br/index.php/RevEnvelhecer/article/view/20683/26989

15. Emmel MLG, Paganelli LO, Valio GT. Uso do tempo de um grupo de idosos do município de São Carlos (SP), Brasil. RKG [Internet]. 2015 [cited 2017 May 1];18(2):421-42. Available from: https://revistas.pucsp.br/index.php/kairos/article/view/28388/19956

16. Nunes AC, Emmel MLG. O uso do tempo nas atividades cotidianas. Rev Ter Ocup[Internet]. 2015 [cited 2017 May 1];26(2):17685. Available from: www.revistas.usp.br/rto/article/download/89617/101713

17. Camarano AA, Kanso K. Como as famílias brasileiras estão lidando com os idosos que demandam cuidados e quais as perspectivas futuras? a visão mostrada pelas PNADs. In: Camarano AA. (Ed.). Cuidados de longa duração para a população idosa: um novo risco social a ser assumido? Rio de Janeiro: IPEA; 2010. p. 93-122.

18. Souza MTS, Silva, MD, Carvalho R. Revisão integrativa: o que é e como fazer. Einstein [Internet]. 2010[cited 2017 May 1];8(1):1026. Available from: http://www.scielo.br/pdf/eins/v8n1/pt_1679-4508-eins-8-1-0102.pdf

19. Clipp EC, Moore MJ. Caregiver time use: an outcome measure in clinical trial research on Alzheimer's disease. Clin Pharmacol Ther [Internet]. 1995 [cited 2016 Apr 22];58(2):228-36. Available from: https://www.ncbi.nlm.nih.gov/pubmed/7648773

20. Davis KL, Marin DB, Kane R, Patrick D, Peskind ER, Raskind MA, et al. The Caregiver Activity Survey (CAS): development and validation of a new measure for caregivers of persons with Alzheimer's disease. Int J Geriatr Psychiatry[Internet]. 1997 [cited 2017 May 1];12(10):978-88. Available from: https://www.ncbi.nlm.nih.gov/pubmed/9395929

21. Marin DB, Dugue M, Schmeidler J, Santoro J, Neugroschl J, Zaklad G, et al. The Caregiver Activity Survey (CAS): longitudinal validation of an instrument that measures time spent caregiving for individuals with Alzheimer's disease. Int J Geriatr Psychiatry [Internet]. 2000 [cited 2016 May 5];15(8):680-6. Available from: https://www.ncbi.nlm.nih.gov/pubmed/10960880

22. Stevens AB, Coon D, Wisniewski S, Vance D, Arguelles S, Belle S, et al. Measurement of leisure time satisfaction in family caregivers. Aging Ment Health [Internet]. 2004 [cited 2017 May 1];8(5):450-9. Available from: https://www.ncbi.nlm.nih.gov/ pubmed/15511743

23. Feldman $\mathrm{HH}$, Van Baelen B, Kavanagh SM, Torfs KE. Cognition, function, and caregiving time patterns in patients with 
mild-to-moderate Alzheimer disease: a 12-month analysis. Alzheimer Dis Assoc Disord [Internet]. 2005 [cited 2016 May 5];19(1):29-36. Available from: https://www.ncbi.nlm.nih.gov/pubmed/ 15764869

24. Van den Berg B, Spauwen P. Measurement of informal care: an empirical study into the valid measurement of time spent on informal caregiving. Health Econ [Internet]. 2006 [cited 2017 May 1];15(5):447-60. Available from: https://www.ncbi.nlm.nih. gov/pubmed/16389664

25. Taylor DH Jr, Kuchibhatla M, Østbye T. Trajectories of caregiving time provided by wives to their husbands with dementia. Alzheimer Dis Assoc Disord [Internet]. 2008 [cited 2016 May 5];22(2):131-6. Available from: https://www.ncbi.nlm.nih.gov/ pubmed/18525284

26. Neubauer S, Holle R, Menn P, Grossfeld-Schmitz M, Graesel E. Measurement of informal care time in a study of patients with dementia. Int Psychogeriatr[Internet]. 2008 [cited 2016 May 5];20(6):1160-76. Available from: https://www.ncbi.nlm.nih.gov/ pubmed/ 18606044

27. Wimo A, Jonsson L, Zbrozek A. The Resource Utilization in Dementia (RUD) instrument is valid for assessing informal care time in community-living patients with dementia. J Nutr Health Aging [Internet]. 2010 [cited 2016 May 5];14(8):685-90. Available from: https://www.ncbi.nlm.nih.gov/pubmed/20922346

28. Shahly V, Chatterji S, Gruber MJ, Al-Hamzawi A, Alonso J, Andrade LH, et al. Cross-national differences in the prevalence and correlates of burden among older family caregivers in the World Health Organization World Mental Health (WMH) Surveys. Psychol Med [Internet]. 2013 [cited 2017 May 1];43(4):865-79. Available from: https://www.ncbi.nlm.nih.gov/pubmed/22877824

29. Haro JM, Kahle-Wrobleski K, Bruno G, Belger M, Dell'Agnello G, Dodel R, et al. Analysis of burden in caregivers of people with Alzheimer's disease using self-report and supervision hours. J Nutr Health Aging [Internet]. 2014 [cited 2016 May 5];18(7):67784. Available from: https://www.ncbi.nlm.nih.gov/pubmed/25226106

30. Hughes TB, Black BS, Albert M, Gitlin LN, Johnson DM, Lyketsos CG, et al. Correlates of objective and subjective measures of caregiver burden among dementia caregivers: influence of unmet patient and caregiver dementia-related care needs. Int Psychogeriatr [Internet]. 2014 [cited 2016 May 5];26(11):1875-83. Available from: https://www.ncbi.nlm.nih.gov/pubmed/25104063

31. Kraijo H, van Exel J, Brouwer W. The perseverance time of informal carers for people with dementia: results of a two-year longitudinal follow-up study. BMC Nurs [Internet]. 2015 [cited 2016 Apr 22];14:56. Available from: https://www.ncbi.nlm.nih. gov/pubmed/26549986

32. Hajek A, Brettschneider C, Ernst A, Posselt T, Wiese B, Prokein J, et al. Longitudinal predictors of informal and formal caregiving time in community-dwelling dementia patients. Soc Psychiatry Psychiatr Epidemiol [Internet]. 2016 [cited 2017 May 1];51(4):60716. Available from: https://www.ncbi.nlm.nih.gov/pubmed/26498751

33. Oldenkamp M, Hagedoorn M, Slaets J, Stolk R, Wittek R, Smidt N. Subjective burden among spousal and adult-child informal caregivers of older adults: results from a longitudinal cohort study. BMC Geriatr [Internet]. 2016 [cited 2017 May 1];16(1):208. Available from: https://www.ncbi.nlm.nih.gov/pubmed/27923347

34. Vaingankar JA, Chong SA, Abdin E, Picco L, Jeyagurunathan A, Zhang Y, et al. Care participation and burden among informal caregivers of older adults with care needs and associations with dementia. Int Psychogeriatr [Internet]. 2016 [cited 2017 May 1];28(2):221-31. Available from: https://www.ncbi.nlm.nih.gov/pubmed/ 26478530

35. Pinquart M, Sörensen S. Correlates of physical health of informal caregivers: a meta-analysis. J Gerontol B Psychol Sci Soc Sci [Internet]. 2007 [cited 2017 May 1];62(2):P126-37. Available from: https://www.ncbi.nlm.nih.gov/pubmed/17379673

36. Fonareva I, Oken BS. Physiological and functional consequences of caregiving for relatives with dementia. Int Psychogeriatr [Internet]. 2014 [cited 2017 May 1];26(5):725-47. Available from: https://www.ncbi.nlm.nih.gov/pubmed/ 24507463

37. Neri AL, Yassuda MS, Fortes-Burgos AC, Mantovani EP, Arbex FS, Torres SVS, et al. Relationships between gender, age, family conditions, physical and mental health, and social isolation of elderly caregivers. Int Psychogeriatr [Internet]. 2012 [cited 2017 May 1];24(3):472-83. Available from: https://www.ncbi.nlm.nih.gov/pubmed/ 21929829

38. Jowsey T, McRae I, Gillespie J, Banfield M, Yen L. Time to care? health of informal older carers and time spent on health related activities: an Australian survey. BMC Public Health [Internet]. 2013 [cited 2016 Apr 22];13(1):374. Available from: https://www. ncbi.nlm.nih.gov/pubmed/23607727

39. Zegwaard MI, Aartsen MJ, Grypdonck MH, Cuijpers P. Differences in impact of long term caregiving for mentally ill older adults on the daily life of informal caregivers: a qualitative study. BMC Psychiatry [Internet]. 2013 [cited 2017 May 1];13:103. Available from: https://doi.org/10.1186/14 